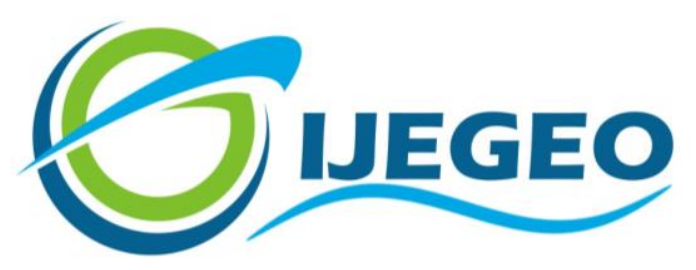

International Journal of Environment and Geoinformatics (IJEGEO) is an international, multidisciplinary, peer reviewed, open access journal.

\title{
State of the art of greenway concept application in Tunisian green policy: A case study of an urban landscape in Sousse city
}

\section{Safa Bel Fekih Bousemma, Faiza Khebour Allouche, Ikram Saidane, Yosra Mechmech and Taoufik Bettaieb}

\author{
Editors \\ Prof. Dr. Cem Gazioğlu, Prof. Dr. Dursun Zafer Şeker, Prof. Dr. Ayşegül Tanık, \\ Prof. Dr. Şinasi Kaya, Assist. Prof. Dr. Volkan Demir,
}

Scientific Committee (2018)

Assist. Prof. Dr. Abdullah Aksu, Prof. Dr. Bedri Alpar, Prof. Dr. Gülşen Altuğ, Prof. Dr. Lale Balas, Prof. Dr. Can Balas, Prof. Dr. Levent Bat, Prof. Dr. Bülent Bayram, Prof. Dr. Nuray Çağlar, Prof. Dr. Jadunandan Dash, Prof. Dr. A. Evren Erginal, Assoc. Prof. Dr. Ali Ertürk, Dr. Dieter Fritsch, Dr. Amin Gharehbaghi, Assoc. Prof. Dr. Tolga Görüm, Prof. Dr. Melike Gürel, Dr. Hakan Kaya , Prof. Dr. Fatmagül Kılıç, Assoc. Prof. Dr. Maged Marghany, Prof. Dr. Nebiye Musaoğlu, Prof. Dr. Masafumi Nakagawa, Prof. Dr. Haluk Özener, Prof. Dr. Erol Sarı, Prof. Dr. Elif Sertel, Prof. Dr. Nüket Sivri, Assoc. Prof. Dr. Füsun Balık Şanlı, Prof. Dr. Uğur Şanlı, Assoc. Prof. Dr. Hasan Özdemir, Prof. Dr. Taşkın Kavzoğlu Assoc. Prof. Dr. Oral Yağcı, Prof. Dr. Seyfettin Taş, Assoc. Prof. Dr. Ömer Suat Taşkın, Assoc. Prof. Dr. İ. Noyan Yılmaz, Assist. Prof. Dr. Baki Yokeş, Assit. Prof. Dr. Sibel Zeki

Abstracting and Indexing: DOAJ, Index Copernicus, OAJI, Scientific Indexing Services, JF, Google Scholar 


\title{
State of the art of greenway concept application in Tunisian green policy: A case study of an urban landscape in Sousse city
}

\author{
Safa Bel Fekih Bousemma ${ }^{1,2, *}$, Faiza Khebour Allouche ${ }^{2,3}$, Ikram Saidane ${ }^{2}$, Yosra \\ Mechmech $^{4}$, Taoufik Bettaieb ${ }^{1}$
${ }^{1}$ B.P 47,4042 Chott Meriem Sousse-Tunisia, Sousse University, High institute of Agronomic Science of Chott Mareiem, Departement of Horticultural Sciences and Landscape
${ }^{2}$ B.P 43, Avenue Charles Nicolle. 1082 Tunis Mahrajène-Tunisia, Carthage University, National Agronomic Institute of Tunis, Laboratory of Horticultural Sciences
${ }^{3}$ B.P 43, Avenue Charles Nicolle. 1082 Tunis Mahrajène-Tunisia, Carthage University, National Agronomic Institute of Tunis, Lr GREE TEAM (LR17AGR01)
${ }^{4}$ Municipality of Sousse-Tunisia, Green space direction

Corresponding author* Tel: +21669313 385

Received 15 Nov 2017

E-mail: belfekihsafa@gmail.com

Accepted 01 Mar 2018

\begin{abstract}
This paper is about the concept of the greenways in Tunisia, defined as a structure allowing to connect the green spaces between them. Two steps have been applied to assess the use of greenway concept in Tunisia and especially in Sousse city. The first one shows Tunisian administrative documents recount and the second one explains the spatial distribution of Sousse city greenways using GIS software. The examination of the planning of the green spaces in Tunisia, either through the documents of town planning or through the specific programs, allowed us to reveal the place of this notion in the Tunisian political speech and to conclude that the notion of greenways and its foundations, is missing in the documents of town planning, in the Tunisian environmental policy (Green Plan of Grand Sousse) even if the use of the term "greenways" is not really explicit. Then, it is our belief that there is a great potential in Tunisia for the adoption of greenways as a planning alternative, and tools such as the GIS environment can contribute significantly to this effort.
\end{abstract}

Keywords: GIS, Green space, Greenways, Urban landscape

\section{Introduction}

To introduce this notion, literature treating greenways is showed in three sections about its general functions such as linearity, spatial scale, multifunctionality and sustainability.

Far from being a neologism, the notion of greenways decades from hundred years. It was similar to the vision developed by the landscape architect Frederick Law Olmsted (18221903), as being avenues, walks or greenways and defined as " a network of linear spaces which is conceived, planned and managed in various purposes: ecological, entertaining, cultural, esthetic or any other compatible objective with the notion of long-lasting sustainable use of the territory ". It is the first definition of the term based on a linear concept. However, the historical roots of the greenway idea are more than 100 years old. They can be found in the blue line concept that defined the Adirondack Park Region, in metropolitan open space systems that were designed and implemented in a number of US cities in the latter decades on the nineteenth and the early decades of the twentieth centuries, to a lesser extent in the greenbelt concept advanced by Ebenezer Howard in 1898, in the adaptation of the Adirondack Park concept to contemporary landscape protection programs, and in a number of linear units of the National Park System that were established in the 1930s (Newton, 1971; Heckscher, 1977). In addition, the so-called green line concept that emerged in the 1970s contributed to this evolution, as did awareness of the development and land ownership patterns in English and Welsh national parks and the creation of the Scenic Rivers, Scenic and Recreational Trails programs by the US 
Congress in the 1960s. The system expanded over time and became known as the Emerald Necklace (Zaitzevsky, 1982). It was after defined as "linear open space established either along a natural corridor, such as a riverfront, stream valley, or ridgeline, or overland along a rail road right-of-way that has been converted to recreational use, a canal, a scenic road, or other route" (Little, 1990). Then, many USA`s authors have moved towards an acceptance of the term (Flink and Searns, 1993; Smith and Hellmund, 1993; Zube, 1995 and Fabos, 1995). Looking at the two root words, 'green' and "way" was the best way to define this concept, such as Searns (1995): “'Green' suggests areas that are left vegetated and in most cases appear or at least strive-to be natural. The word "way" implies movement, getting from here to there, from point to point. This is the important distinguishing feature of greenways-they are routes of movement-for people, for animals, for seeds, and, often, for water".

The second definition of greenway is based on spatial scale; more greenways have been developed to link together on different scales to form local and regional networks. In China, greenways were introduced initially as a type of spatial network (Liu and Yu, 2001). This concept was taken back a little later (1908), in France by the landscape painter Jean-ClaudeNicolas Forestier ( 1861-1930) who expressed through his book " Big cities and system of parks ", the necessity of thinking of the urban development from a " system of parks " including spaces of different scales going from " big reserves and protected landscapes " to the " grounds of recreation " including " avenues walks ", the " suburban parks ", the " big urban parks ", the " small parks " up to the " district garden ". The continuity between these various spaces help create" a network" of vegetated spaces in the city what contributes to the development of the interesting landscapes. These systems (systems of parks) can be then considered as the ancestors of greenways (Arrif et al., 2011). In the early stages, greenways were developed as individual linear spaces, while in recent years planners have proposed the concept of a greenway network (GN) that links different greenways to provide a green matrix for better connections between cities and nature and a counterbalance to the built environment (Kullmann, 2013).

Recently, this notion was re-appropriated and adopted by the landscape painters because it is about a multifunctional notion susceptible not only to improve the living environment of the inhabitants but also to impulse a socioeconomic growth to which aspire the actors of the territory but also of the inhabitants today (Cormier et al., 2009). In general, greenways are regarded as having multiple functions, such as ecologically significant corridors (Ergen, 2013; Linehan, Gross, and Finn, 1995; Miller, Collins, Steiner, and Cook, 1998), recreational places (Tzolova, 1995; Vasconcelos and Pritchard, 2007), and paths with historical or cultural significance (Fábos, 1995; Pena, Abreu, Teles, and Espirito-Santo, 2010).

Greenways are not only for the protection of nature. Other human uses of the landscape are recognized and legitimized, and a balance between resource use and protection is attempted. Sustainability should be regarded as a special globally accepted goal and paradigm (IUCN, 1980; WCED, 1987; Lyle, 1994). They help maintain biological diversity, protect water resources, conserve soils, support recreation, enhance community and cultural cohesion, and provide species migration routes during climate or seasonal change (Forman, 1983, 1995; Forman and Godron, 1986). Greenways, sometimes referred to as environmental corridors, landscape linkages, wildlife corridors, or riparian buffers, provide an important means to both protect natural areas and to provide recreation opportunities (Little, 1990). They can help to maintain ecological integrity in human-dominated landscapes, especially with regard to sustaining highquality water reserves and preserving biological diversity (Smith and Hellmund, 1993; Burak et al., 2009; Gazioğlu et al., 2016).

The greenways strategy is consistent with the concept of sustainable development, in that it is based on an assumed complementarity between nature protection and economic development (Ahern, 1995). Greenways contribute to many ecological and societal values (Fabos, 1995). From the social sustainability perspective, greenways play a key role in connecting people 
to the rural resources and workplace in their daily lives. In particular, greenways create a link between communities and specific features such as farms, natural parks, woodlands, archaeological and architectural sites and residential areas, as well as providing recreation, expanding rural tourism and promoting the recovery of disused facilities and architectural goods (Audirac, 1997). This is specifically true when such situations involve the public and sustainable development issues, and affect the community on local, regional, national, and global scales (Jankowski and Nyerges, 2001; Campagna, 2006). Therefore, greenways are different from either green infrastructures or non-motorized systems, as they provide a balance between nature and daily life (Liu et al., 2016).

However, different applications of greenway concept have been applied, in Mediterranean landscapes. From example, in Italy, the Lambro River Valley Park project aims to plan a greenway network for connections: between people and the land, between public parks, natural areas, historic sites and other open spaces (McMahon, 1993). In Portugal, several studies have showed the importance of spatial distribution of resources in defining greenways network for the Metropolitan Lisbon Area (Machado et al., 1995; Ribeiro, 1998). More recently, in the same Italian area, authors have allowed the development of a greenways network incorporating the existing network of green trails: $80 \%$ of the network is, in fact, already in place. The methodology also proved to be useful in the definition of a network dedicated to non-motorized traffic capable of connecting the numerous urban centers with the many resources present in the area (Toccolini et al., 2006; Musaoğlu et al., 2004 and 2006). In El-Sadat City-Egypt, Ahmed Mahmoud and Adel El Sayed (2011) have proposed a method of green network planning that would help in enhancing the connectivity and reduce fragmentation though integrated greenway system by using GIS. Recently, for evaluating the perceptions and preferences users in urban greenways, Akpinar (2016) has found that for Turkish people, urban greenways are more than a "luxury" and could provide important health, recreational, and leisure activities. Eight factors are defined affecting urban greenways.
As the above-cited literature demonstrates, greenways as a part of urban green infrastructure system have the capability to connect communities and provide recreational resources in cities (Fábos, 2004). The popularity of urban greenways has increased because of their recreational, environmental, economic, and social functions, as well as other benefits to the cities in which they were implemented. That is why significant attention is now being paid to urban greenways (Lindsey et al., 2001). However, despite the fact that the majority of the urban population in the world live in developing countries, researches on urban greenways are often carried out in developed western countries (Wright Wendel et al., 2012), with relatively little known about user preferences and factors affect greenways use in urbanizing cities in developing countries (Willemse, 2010). In addition, relationship between greenway design features and patterns of use of greenways is understudied (Lindsey et al., 2008). Therefore, the purpose of this study is to study the place of greenway notion in Tunisian green politics. The objective of this research is to see the reality of this notion in Tunisia, if it exists or not in political speech and texts of Tunisian national programs of green spaces creation and more particularly in regional Green Plans. Then, it is essential to verify, through the choice of a site study, the real application of the notion and not in speeches what allowed us to carry our conclusions as for whether a greenways exists in Tunisia or not.

\section{Materials and Methods}

Two steps have been applied to assess the use of greenway concept in Tunisia and especially in Sousse city. The first one shows Tunisian administrative documents recount and the second one explains the spatial distribution of Sousse city greenways using GIS.

\section{Tunisian administrative documents}

For controlling urban development, greenways act as greenbelts separating urban areas from the surrounding landscape and thus controlling urban sprawl (Kühn, 2003; Yang and Jinxing, 2007; Fitzsimons et al., 2012). Urban areas are highly modified and complex landscapes, within which green or open areas are seen as 
valuable for human well-being as well as wildlife (Pickett et al., 2001, 2004). However, urban green infrastructure is an essential part of urban network that serves the interests of both people and nature. Green infrastructure is defined as the combined structure, position, connectivity and types of green spaces in and around cities that together provide improved quality of life and ecosystem services (Forest Research, 2010; Foster et al., 2011). Urban green spaces (UGS) are an essential part of urban green infrastructure system (Orr et al., 2014). UGS comes in many forms and the greenway is one of them ( Akpınar, 2016). The various documents of Tunisian planning revealed are Master Plan of Arrangement, Urban Spatial Planning and Plans of Housing Schemes and specific programs dedicated to green spaces development are listed for five programs: National Urban Parks Program, National Project for Environmental Cleanliness and Esthetics, National Program of Environmental Boulevards, National Program of Earth Boulevards and Program of Green Spaces Promotion.

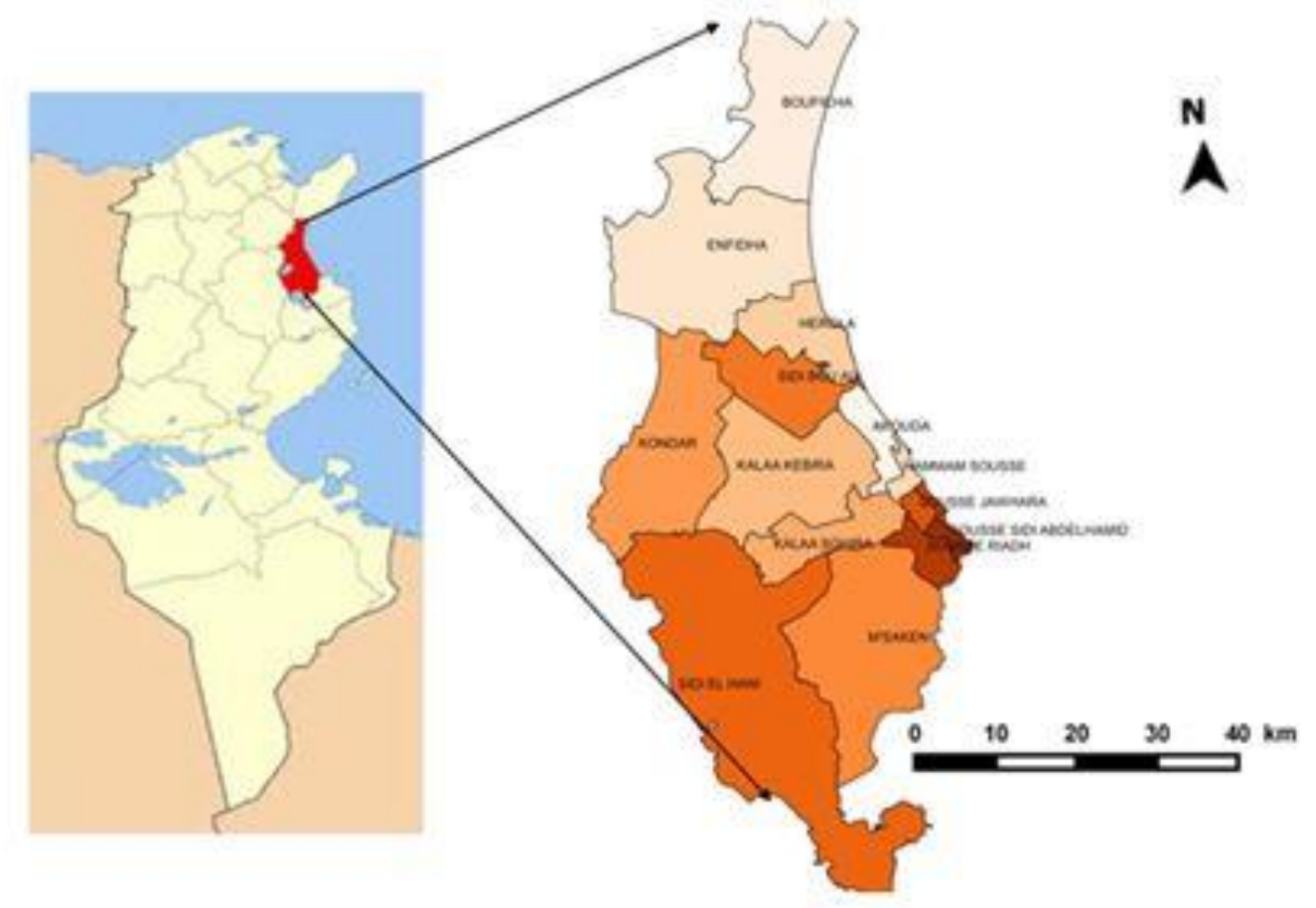

Fig 1. Geographic location of the study area

\section{Study area}

The study area is located in eastern costal zones: $35^{\circ} 49^{\prime} 32^{\prime \prime}$ North, $10^{\circ} 38^{\prime} 28^{\prime \prime}$ East of Tunisia with an area of $2669 \mathrm{~km}^{2}$, is formed by four districts: Sousse Nord, Sousse Medina, Sousse Sud and Eriadh city which form a single urbanised mass, welded around large cities in the direction of the North and in the South (Figure1). Sousse Governorate includes 16 delegations, 16 towns and 8 rural councils. It is characterized by mild-cold winters and semiarid continental climate with an average yearly rainfall about $320 \mathrm{~mm}$ with a minimum and a maximum average annual temperature of

$12.74^{\circ} \mathrm{C}$ and $38.48^{\circ} \mathrm{C}$. This area is known by a culture diversification and landscapes that have sustained the development of tourism. The soil occupation is dominated by the presence of the olive groves characterized by their economic wealth and landscape beauty. The city of Sousse fast stood out as an excellent site of studies. Indeed, Sousse municipality, seat of the governorate, it has obtained the label citygarden since December 2009, and has due to this fact several green spaces and fitted out axes the distribution of which it is possible to study.

Various methodologies can be found in the literature for planning greenways, such as those described in Flink and Searns (1993), Smith 
and Hellmund (1993), Baschak and Brown (1995), Tzolova (1995), Linehan et al. (1995), Shannon et al. (1995), Bueno et al. (1995), Giordano (2000), Giordano (2004), Ribeiro and Barão (2006), Toccolini et al. (2006), and Walmsley (2006). The data set covers the sales of houses and apartments in the city of Sousse, Tunisia. The data from Sousse municipality was inconsistently mapped by using Mapinfo 6.3 software and three shape files have been collected: green spaces (linear, polygon) and urban base map. However, in international litertature different kinds of green spaces typology can be found, but typology used in this research is adapted from Carr et al. (1992), Panduro et al. (2013) and from Cvejić et al. (2015), whose eight types of green spaces are defined:

- Institutional green space: green spaces surrounding public and private institutions and corporation buildings (clinics, hospitals, hotels, educational institutions, youth clubs, public administrations).

- Cemetery and churchyard: burial ground often with covered by lawns, trees and other ornamental plants.

- Plantations: trees planted along roads and paths either solitary or in rows. Hedges along roads or paths (Tree alley and street tree, hedge).

- Parks: green space categorized as a park has a high maintenance level with well-kept vegetation and a wide range of recreational possibilities. Footpaths open the green area to the public and make it possible to walk in the area and enjoy different features such as small lakes, trees, lawns, flowers, and sport activities.

- Urban park: Open space developed in residential environments; publicly developed and managed as part of the zoned open space of cities, or as part of new private residential development; may include playgrounds, sport facilities, etc.

- Public gardens: neighborhood spaces designed, developed or managed by local residents on vacant land; may include viewing gardens, play areas, and community gardens; often developed on private land; not officially viewed as part of open space system of cities; often vulnerable to displacement by other uses such as housing and commercial development.
- Square or plaza: often part of historic development of city center; may be formally planned or exist as a meeting place of streets; frequently publicly developed and managed.

- Traffic roundabouts: is a type of circular intersection or junction in which road traffic flows who are managed and planted.

The final map of green space in Sousse has a precision and quality which we consider to be adequate to feed into the analysis.

\section{Results}

The development of suitability analysis has a strong tradition within landscape planning (Hills, 1961; McHarg, 1969; Murray et al., 1971; Steinitz et al., 1976; Steiner, 1983; Linden, 1984; Banai- Kashani, 1989; Searns, 1995; McHarg, 1996; Fábos and Ryan, 2006 ).

The primary benefit of any application of the connectivity and greenway concepts to landscape management is the ability to restore connectivity throughout the landscape (Viles et al., 2001). In recent year, the greenways concept has been adopted as a planning alternative and tools such as multi-criteria spatial decision analysis and the GIS environment can contribute significantly to this effort (Giordano et al., 2008). The objective of this article is, let us remind it is seeing the way the green spaces are distributed and if there is a possible connection between them through the study of the case of the city of Sousse. The followed approach included at first the reading of the contents and the objectives of the documents of planning of the green spaces to reveal indications revealing the political will to create a green weft. It is acts then of seeing its realization on the ground. It allowed to end in two different results.

\section{Tunisian green space policy}

Green spaces planning has double approach: as a matter of planning, green spaces are thrown according to two steps: an approach of urban planning which gets shape with various documents of town planning, and an approach of projects with the specific programs dedicated to the development of green spaces (Turki S., Zhioua I., 2006). Tunisian town planning 
documents appears at various scales: the Master Plan of Town and Country Planning that fixes orientations of arrangement on a national scale whereas Master Plan of Planning is developed on the scale of governorates. The urban planning is made on municipality scale and creates Urban Spatial Planning. Then, Housing Schemes Plans which are developed on district scale and have to be in accordance with the specifications of National Town Plan. According to the Urbanism Code of Town and Country Planning, the free or wooded spaces as well as the landscapes either urban or natural to maintain or to create have to appear on the cartographic documents of the Master Plan of Planning. The arrangement of green zones, city parks and natural spaces have to appear in the schedule plan, establishing the outcome of the Master Plan of Planning, as well as the set of programs relative to the basic infrastructure, big equipment and services as well as the planning and the highlighting of the archeological and historic sites. The Urban Spatial Planning, documents of urban planning and regulations of soil uses realized by local authorities, are the main regulatory framework in which are bounded zones with green space vocation. Any zone cannot have another type of activity. The change of statutory vocation of green space can take place only by means of a presidential decree as it is stipulated in the Urbanism Code of Town and Country Planning (1994).

In practice, all existing green spaces city are either scheduled and realized from the Urban Spatial Planning, or integrated into these documents during their revision. It's the main document from which it is possible to determine set location of green spaces city. It allows to define the system of green spaces in the absence of a specific planning. The planning of green spaces is also made through the specific programs generated by the Environmental Ministry as the National Program of Urban Parks and the Program of
City Gardens. This program was thrown at the beginning of 1990s to shape a "green policy" which aims at the realization of hundred parks on all the Tunisian territory. The National Project for Environmental Cleanliness and Esthetics is a project realized with the support of the National Agency of Environmental Protection. Among others actions, it attributes to cities which fill a number of criteria, the label city-garden. It can be so considered as generator of green spaces because he incites municipalities to realize public gardens on their territory. To aspire to the label of city-garden, the candidate city has to have a minimum of 14 $\mathrm{m}^{2}$ of green spaces per inhabitant, have least five important green spaces among which an urban park as well as a boulevard of the environment and at least three well fitted out main arteries. Within the framework of the promotion of urban esthetics of Tunisian cities, two other programs were adopted; it is about Boulevards national program in every municipality and about the national program of Boulevards creation of the earth in every municipality seat of governorate. The National program of green spaces promotion comes to be added to the list mentioned above to increase the ratio of green spaces considered still too low. Other tools of urban and environmental planning come to be added to this list and we can mention the Green Plan which aims at setting up a policy of conservation and valuation of "natural spaces" and at strengthening the presence of nature in town.

\section{Assessment of green space projects in Sousse City}

The following table fitted out the specific programs dedicated to the development of Tunisian green spaces, their aims and an example for every one realized in Sousse city. 
Table 1. Specific programs dedicated to the development of Tunisian green spaces.

\begin{tabular}{|c|c|c|c|}
\hline Program & Creation year & Objectives & Example \\
\hline $\begin{array}{l}\text { The National Program of } \\
\text { Urban Parks }\end{array}$ & 1990 & $\begin{array}{l}\text { *to endow the big cities } \\
\text { of urban parks, } \\
\text { * to suppose equipment } \\
\text { for improving the living } \\
\text { environment of city- } \\
\text { dwellers, } \\
\text { *to preserve the suburban } \\
\text { forests. }\end{array}$ & $\begin{array}{l}\text { Urban Park of Hmedet } \\
\text { Douik, in Sousse on } \\
2010 .\end{array}$ \\
\hline $\begin{array}{l}\text { The National Project For } \\
\text { Environmental } \\
\text { Cleanliness And } \\
\text { Esthetics }\end{array}$ & 1996 & $\begin{array}{l}\text { *to upgrade } 30 \text { Tunisian } \\
\text { cities, in areas related to } \\
\text { the living environment of } \\
\text { citizens, } \\
\text { *to integrate } \\
\text { environmental protection } \\
\text { in sustainable } \\
\text { development strategy for } \\
\text { the quality of life. }\end{array}$ & $\begin{array}{l}\text { The municipality of } \\
\text { Sousse obtained the label } \\
\text { city-garden on December } \\
2009 \text {. }\end{array}$ \\
\hline $\begin{array}{l}\text { The National Program of } \\
\text { Environmental } \\
\text { Boulevards }\end{array}$ & 1996 & $\begin{array}{l}\text { *to promote urban design } \\
\text { of Tunisian cities, } \\
* \text { to improve statements } \\
\text { of main roads, } \\
\text { *to create } 10 \mathrm{~m}^{2} \text { of green } \\
\text { space per inhabitant with } \\
\text { the beginning of } 2000, \\
\text { *to exploit treated water } \\
\text { to irrigate green spaces. }\end{array}$ & $\begin{array}{l}\text { In } 2007 \text {, the ministry has } \\
\text { provided to the } \\
\text { municipality of Sousse a } \\
\text { financial contribution } \\
\text { ( } 57,000 \text { dinars) to create } \\
\text { the environmental } \\
\text { boulevard of Sidi } \\
\text { Abdelhamid, Sousse. }\end{array}$ \\
\hline $\begin{array}{l}\text { The National Program of } \\
\text { Earth Boulevards }\end{array}$ & 1996 & $\begin{array}{l}\text { *to aim the National } \\
\text { Program } \\
\text { Environmental } \\
\text { Boulevards. }\end{array}$ & $\begin{array}{l}\text { In } 2000, \text { the ministry } \\
\text { provided to Sousse } \\
\text { municipality a financial } \\
\text { contribution }(14000 \\
\text { dinars) to create the Earth } \\
\text { boulevard. }\end{array}$ \\
\hline
\end{tabular}




\begin{tabular}{|c|c|c|c|}
\hline $\begin{array}{l}\text { The National program of } \\
\text { green spaces promotion }\end{array}$ & 1996 & $\begin{array}{l}\text { *to promote urban design } \\
\text { of Tunisian cities, } \\
\text { *to contribute to the } \\
\text { creation of } 10 \mathrm{~m}^{2} \text { of } \\
\text { green space per } \\
\text { inhabitant with the } \\
\text { beginning of } 2000 .\end{array}$ & $\begin{array}{l}\text { - management of Sidi } \\
\text { Yahia square in the } \\
\text { framework of a Tunisian } \\
\text { cooperation Dutch, in } \\
\text { 1997; } \\
\text { - construction of a } \\
\text { Sahloul square as part of } \\
\text { local agenda } 21 \\
\text { implementation, in 2006; } \\
\text { - implementation of } \\
\text { Kalaa Sghira road } \\
\text { beautification, in 2007; } \\
\text { - management of } \\
\text { Ramparts garden, in } \\
\text { 2009. }\end{array}$ \\
\hline
\end{tabular}

After the revolution, the large-scale urban development operations are based to rehabilite green spaces and nearby gardens city due to urban saturation, so there is no more space for creating new green spaces. Therefore, since 2012, three green zones in Sahloul, a green zone in Sahloul 3 and promenade of Ramparts have been managed on the year 2015. The management of green spaces is no more under the legislation of such and such program; it becomes a personal initiative of the municipality whole team. The first report was to collect that, from the point of view of green spaces programming through the documents of town planning, the notion of greenway is not really approached. Contents and objectives of these documents are defined by The Urbanism Code of Town and Country Planning. The latter does not give specific recommendations about green spaces, however, it fixes in its first articles the objectives like preservation of natural, cultural beauty spots and the safeguard zones and " the harmonization between economic development, social development and ecological balances, to guarantee a sustainable development and the citizen's right to a healthy environment " for the management and the planning of urban conglomeration. According to the specific programs, the notion is suggested however timidly through the existence of the national programs of Environmental Boulevards and Earth Boulevards which are the sign of the interest carried in the landscaping of the main urban axes. This is also visible through the criteria to fill for the allocation of the label city-garden. Among those above and further the existence of at least five important green spaces, it is imperative to have at least three main well fitted out arteries roadside trees, street and ambiance lighting, urban furnishing but especially a fitness trail and/or an organized, cultural or touristic circuit. The latter joins the idea of connectivity between the diverse city green spaces. Putting that in mind, the notion of greenways is clearly visible in the Green Plan of Grand Sousse and even if the use of the term " greenways " is not very explicit, its objectives are to join perfectly the foundations of the greenways which is adopted as a real strategy of arrangement. The operational objectives of the Green Plan of Grand Sousse aim at insuring the integration of a system of natural grounds in the urban perimeter. "The new lots and towns must be bordered with green grounds as meadows andlor wooden bands, so that they have a clean identity. The green spaces have to extend to 
nearby the city center of Sousse and so they contribute in an effective way to improve the air quality in the city" (Green Plan of Grand Sousse, 1997).

The objective for year 2017 was to get to approximately 850 ha of green spaces consisting of $20 \%$ (170 ha) of parks and $80 \%$ of natural vegetation. Another very significant objective was the one to create green corridors, planted between parks before the horizon of 2017. The green points which exist must be bound one to another by introducing an extension of boulevards lined by trees, which should create a pleasant atmosphere during the pedestrian walk. The green plan proposes besides, a list of projects the most significant of which are the interpenetrating structure between the green spaces and the urbanized spaces of Grand Sousse on one hand, and extension of the grand boulevards of one somewhere else. The first project is a diagram which is supported by the network of the realized infrastructures and his realization will pass inevitably by the integration of the project in the statutory frame to know the Master plan of Arrangement of Sousse urban area and the urban development plans of the municipalities of Grand Sousse. The implementation of this project goes through a list of stages that we saw worth to enumerate view their importance in the realization of the project:

*The identification and the census of the not urbanized spaces which present a character of fragility (erosion, badly checked urbanization) and a landscaped interest whether they are agricultural zones or natural ones;

*The establishment of a map of the landscapes of Grand Sousse: this document will have to serve the guide in the Urban Spatial Planning to specify the urbanizable spaces and the zones to be possibly restored in the natural or agricultural milieu;

*The modification of the map of classification of agricultural lands to make them more restrictive towards the urbanizable zones;

* The follow-up and the supervision of the not urbanizable zones to envisage and to emphasize in order to avoid the growth of diverse of spontaneous housing zones and various activities;

*The implementation of the plan of landscaped reserves which is to be associated with the investments devoted to the management and the conservation of water (whether it is for the supply, the purification) and in the field investments of farming sector intensification;

*The implementation of mid-term and longterm policy of afforestation of the identified zones, has to be made collaboration of the Governorate and the various municipalities and all the concerned regional offices.

As for the project of grand boulevards network extension, it aims at upgrading the main intermunicipal axes of connection not only at the level of the public road network but also at the level of their landscaping and their landscaped integration in urban structure. It is perfectly in coherence with the project of "interpenetrating structure of Grand Sousse", it indeed suggests, arrangements consolidating the existing landscaped structures and defines actions to be undertaken. What we can conclude through the reading of these documents is that there is a real strategic plan explaining the recommendation of a new mode of arrangement but it would be necessary to see its realization on the ground.

\section{Spatial distribution of Sousse city green spaces}

After a cross-check of the data supplied by the Service of Green Spaces in Sousse Municipality and Regional Direction of the Environment, are considered green spaces, those afforested in more than $50 \%$ of the total surface and open to the public. They include urban parks, public gardens, fitted out traffic roundabouts, fitted out full lands, public institutions gardens (Educational institutions, hospitals, barracks, youth clubs, public administrations ...), hotels green zones of and industrial park of Sidi Abdelhamid, Sebkha of Sousse, as well as plantations (roadside trees which border avenues, road beltways, tourist routes, and scattered trees). 


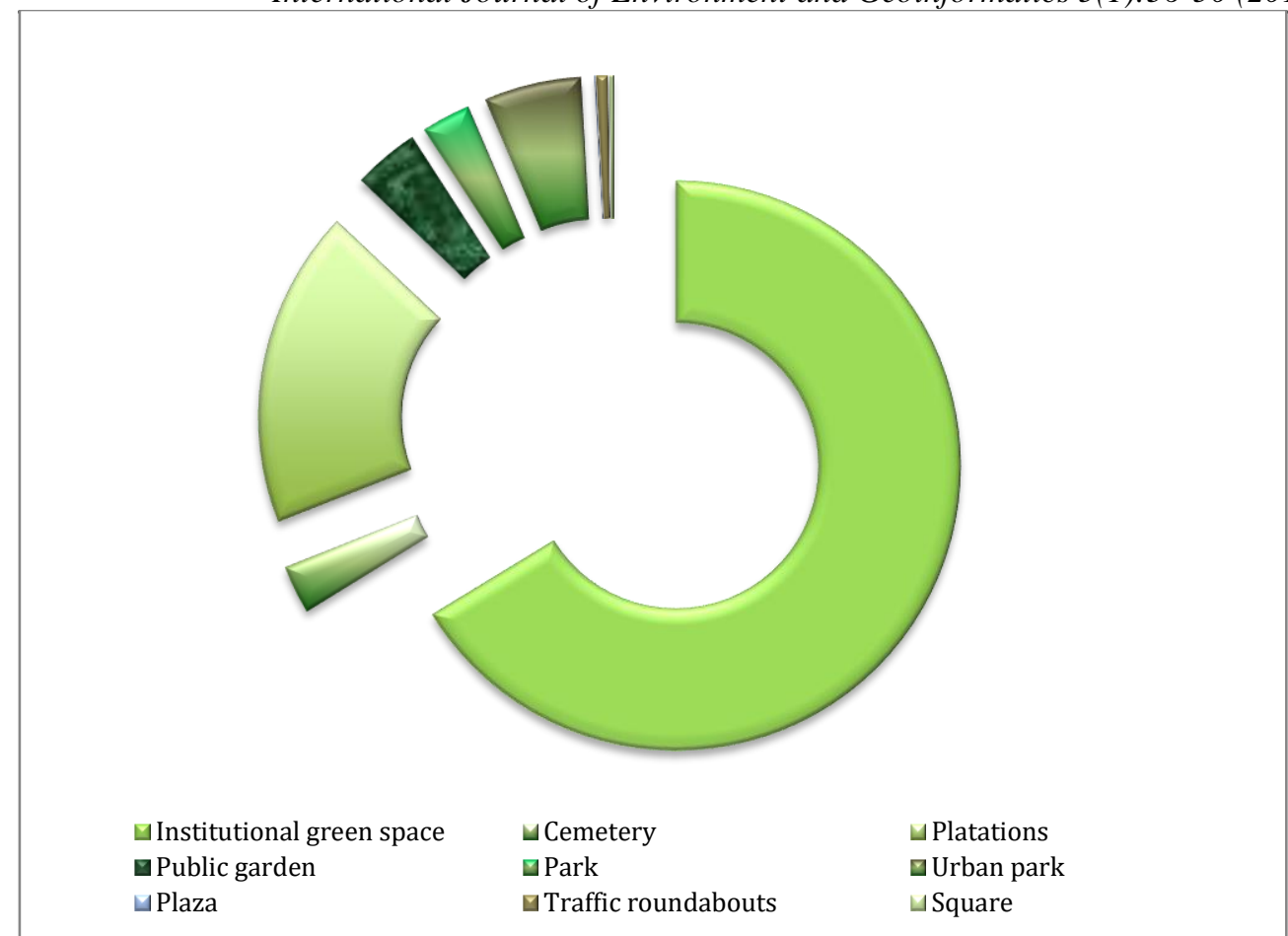

Fig 2.Figure Surface $\left(\mathrm{m}^{2}\right)$ occupied by green spaces in Sousse city.

counts at present five main parks and public gardens (Hsan Ben Saïd garden, park Hmedet

The typology of green spaces adopted by the municipality of Sousse city missed some types like the central reserve and the most gardens of public institutions. After revolution, there is no more study about the environmental situation also about the calculating of green space ratio for every municipality. The city of Sousse Douik, Ibn Eljazzar garden, Boujaafar garden and Ramparts garden) fitted out and exploited as pleasant places of entertainment and leisure for the local population, covering a total surface of 17,3 ha, that is $11,9 \%$ of the total surface of green spaces.

Table 2. Main parks and public garden in Sousse City.

\begin{tabular}{|c|c|c|}
\hline Kind of green space & Name & Surface $\left(\mathrm{m}^{2}\right)$ \\
\hline \multirow{2}{*}{ Park } & Ibn ElJazzar & 12160 \\
\hline & Boujaffar & 18000 \\
\hline Urban Park & Hmedet Douik & 100000 \\
\hline \multirow{2}{*}{ Garden } & Ramparts & 30000 \\
\hline & Hsan Ben Said & 13000 \\
\hline
\end{tabular}


Figure 3 shows a strong disparity between districts stop at. Indeed, green spaces are concentrated in the North and middle part of the city for the benefit of the South part, which is deprived from equipped and fitted out areas for relaxation and leisure activities.

More than that these districts border the industrial zone of Sidi Abdelhamid, and would be the most exposed to the atmospheric pollution. Besides the South zone of Sousse largely shelters families having a low income or a lower educational level, these citizens are the most sensitive to the absence of green spaces which offset for the lack of social support. The bad territorial distribution of the green spaces intensifies more and more the segregation North-South in the city and compromises the balance and the social coherence between districts. In a general way we can say that the urban fabric of the city of Sousse is poor in term of green spaces from where the insufficiency of nearby green spaces which could establish a pressure for the inhabitants.

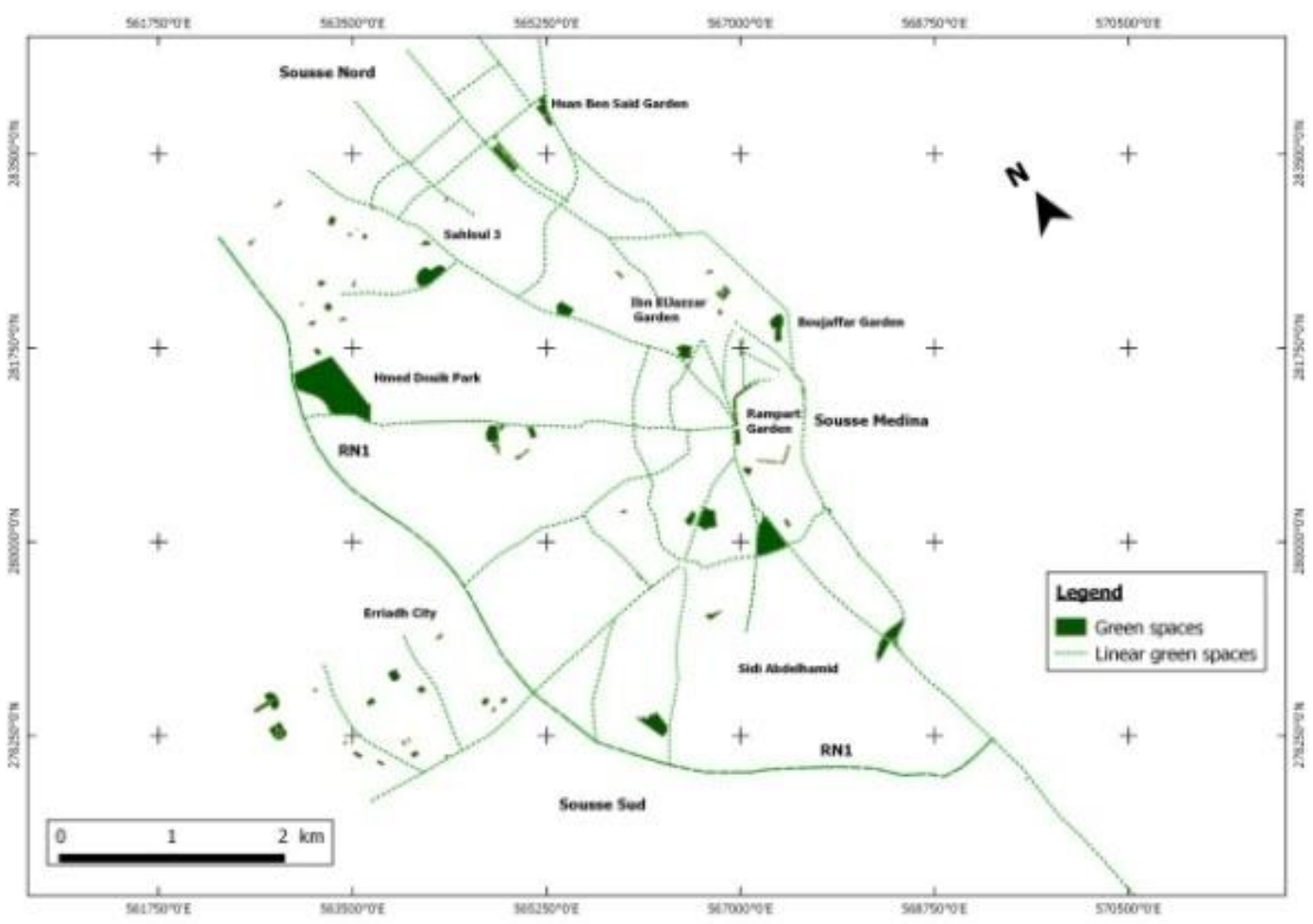

Fig 3. Spatial distribution of Sousse city green spaces.

Inside the city, the fitted out axes do not play the role which is assigned to them by offering to walkers the shade zones, and to get less solar energy compared to the sectors where we find especially buildings, so as to decrease the formation of urban blocks of hot season. All that we have said is not felt on the practical plan, because planted roads or avenues are insufficient from the point of view arrangement and present some problems, a tour in the avenues of the city reveals some are linked to the arrangement itself, others are linked to the maintenance: (a) the distance tree-tree and tree road non respected;

(b) the species of trees are not adapted to the climate;

(c) the absence of railings for the basins of plantations: they must be placed at the foot of trees, to facilitate the traffic on the pavement, in addition they allows the aeration and the water supply and avoids the compaction of the ground at the foot of vegetables;

(d) the size of maintenance of linear trees is a major problem bound to the maintenance, it is very important: because it is necessary to clear a passage enough high for vehicles $(4,50 \mathrm{~m})$ 
and for the pedestrians and it is necessary to insure the safety of the users.

To these defects of management, is added the fact that there is absence of connections between these "fitted out" axes. These various axes do not allow to create quality alignments forming a network, what affects the desired function "that avenues are the areas of walks of the city".

\section{Discussion and Conclusion}

We were able to see that the documents of town planning which are the only statutory tools according to which are bounded zones with vocation of green space, never mention the term " greenway ", even if different orientations emerge from it as the improvement of the living environment, the sustainable arrangement, the conservation of natural resources, etc. In Tunisia, the creation of green spaces in urban zones became a recurring slogan in the speech held by public authorities, and this is in a parallel to the adoption of the above-mentioned principles of "sustainable urban development" and "quality of life" (Dridi, 2009). The green spaces are thus thought regarding ratios of $\mathrm{m}^{2}$ per resident and not as coherent set of structures which can work in a network. The fact that the green spaces are planned on one hand through the documents of town planning and on the other hand, through the specific programs can generate some disconcordances. There is a good reason to indicate that the green spaces planned by the Urban Spatial Planning are not all realized as far as the concerned grounds are the object of no arrangement. Parks realized within the framework of the National Program of Urban Parks are spaces not or little drawn. The arrangements were realized by the public authorities in an improvised way and were not the object of preliminary arrangement study.

They were often executed in the urgency and in a direct way so requiring immediate solutions. The works are generally made in two phases: porticos of entrance, often monumental as well as the beginning of a fence are constructed at first, then the second phase which consists in fitting out the inside of the park. In most of the cases, only a small proportion of the site is fitted out, the rest being left with the natural state, which is a tree-filled wild area (Loukil, 2006). These spaces which were created because of the legislation of certain specific programs, even if they are only sketchily and particularly fitted out, are counted, on their whole surface as a green space and so contribute to quickly reach the goals fixed in term of square meters of green space per resident. The criteria to fill for the attribution of the label City-garden remain however little precise and deserve a critical reading. Indeed, the minimum of $14 \mathrm{~m}^{2}$ per resident required is little significant because it is not related to the grid of equipment and does not take into account the various categories of green spaces defined by this one. It is in continual progress from one year to another. The existence of at least five important green spaces is worthy of note. It is not however specified from which surface a green space is considered as important. The size of the municipality and population is not indicated as a coming into play parameter. Then, the existence of a boulevard of environment without specification of the criteria which a make boulevard considered as boulevard of environment (do we limit ourselves to the name of the way?). Besides, we notice that the arrangement of the boulevard of Environment is only a stereotype repeated going from Bizerte to Tataouine, everything independently of the identity of every city, practically it is about the same style, about the same vegetable range used from the north to the south (the Ficus nitida as a roadside trees and the Nerium oleander for its blooming flowers). The same thing was noted for the boulevard of Earth.

In conclusion, it is our belief that there is a great potential in Tunisia for the adoption of greenways as a planning alternative, and tools such as the GIS environment can contribute significantly to this effort. GIS has been widely used for analyzing the service area of urban green areas by simple "buffering", which involves drawing lines around parks at a given distance (e.g., Phua and Minora, 2004; Store and Kangas, 2001). Bizuwerk et al. (2006) attempted to distinguish suitable areas for flora and fauna, vegetation and forest by embodying different spatial information using GIS 
techniques. The results of Bizuwerk et al. (2006) study show that GIS furnishes a great advantage of spatial and quantitative multilayer analysis of data. Depending on the available spatial data, the accuracy and reliability of the result using GIS application could be enhanced (Mahmoud et al., 2011). Therefore, applying Map.info by the municipality of Sousse city is no more a practical and efficient tool for clearly identifying suitable sites for developing green spaces.

Indeed, in Tunisia and in most Tunisian big cities, the green spaces were born with the extension of the European city outside of the medina where this notion is totally illusory. Tunisia for the matter, has become over the years an attractive tourist destination, from then on, public authorities tried to promote the creation of green spaces by multiplying the National Program of Urban Parks; the arrangement of the entrances of city, the creation of boulevards of the environment in all the Tunisian cities. The creation of green spaces in the urbanized places became a recurrent message in the messages conveying an environmental policy particularly having adhered to the rules of the "sustainable development". We were able to deduct through this study that the green spaces were rationalized as urban equipment just like cultural facilities, sports or of healthy facilities. They were standardized under the shape of $\mathrm{m}^{2}$ per inhabitant (public authorities fixed a minimum of $10 \mathrm{~m}^{2}$ of green spaces / inhabitant). In fact this minimal standard was required moreover for any new project of arrangement. The objective of this work was to see if this "green policy" allowed the creation of "modern" and "well-balanced" urban fabrics and if the distribution of the green spaces contributed to better structure the urbanized spaces operating so in the realization of the rules of greenways, defined as a structuring network allowing to connect the green spaces between them. The examination of the planning of the green spaces in Tunisia, either through the documents of town planning or through the specific programs, allowed us to reveal the place of this notion in the Tunisian political speech and to conclude that the notion of greenways and its foundations, is missing in the documents of town planning, in the Tunisian environmental policy (Green Plan of Grand Sousse) even if the use of the term "greenways" is not really explicit. It is the realization of this concept on the ground that is not obvious as showed the study of the specialization of the green spaces in the city of Sousse. The realization of such a project can be designed only within the framework of the integration of the operational objectives of the green plan within the framework of the statutory tools (Master Plan of planning and Urban Spatial planning) and especially the consideration of the landscaped dimension during the elaboration or during the revision of these documents. The realization of the greenways cannot be a retrospective in an existing urban fabric but rather with a policy of pre-greening as it is the case today of big housing schemes realized by the Real Estate Housing Agency in Tunis, Hammamet or still to Sousse. The lessons learned from these study provide a useful framework for landscape planning and development of future urban greenways, in Tunisia.

\section{References}

Adli Imam and K.Z. El (2006). Role of urban greenway systems in planning residential communities: a case study from Egypt. Landscape and Urban Planning 76 (1-4): 192-209.

Ahern, J. (1995). Greenways as a planning strategy. Landscape and Urban Planning. 33 (1/2): 131-155.

Akpınar, A. (2016). Factors influencing the use of urban greenways: A case study of Aydin, Turkey. Urban Forestry and Urban Greening. 123-131.

Arrif T., Blanc N. and Clergeau P. (2011). Trame verte urbaine, un rapport Nature Urbain entre géographie et écologie. Cybergeo : European Journal of Geography.

Asakawa, S., Yoshida, K. and Yabe, K.(2004). Perceptions of urban stream corridors within the greenway system of Sapporo, Japan. Landscape and Urban Planning 68 (2-3): 167-182.

Audirac, I. (Ed.) (1997). JohnWiley and Sons, Ltd. 
Baschak, L.A. and Brown, R.D. (1995). An ecological framework for the planning, design and management of urban river greenways. Landscape and Urban Planning 33: 211-225.

Binford, M.W. and Buchenau, M.J (1993). Riparian greenways and water resourses. In: Smith, D.S., Hullmund, P.C. (Eds.), Ecology of greenways: Design and Function of Linear Conservation Areas. University of Minnesota Press, Minneapolis, MN.

Bischoff, A. (1995). Greenways as vehicule for expression. Landscape and Urban Planning 33: 317-325.

Bizuwerk, A., Peden,D., Taddese,G. and Getahun, Y. (2006). GIS Application for Analysis of Land Suitability and Determination of Grazing Pressure in Upland of the Awash River Basin, Ethiopia. International Livestock Research Institute. Brail, R.K., Klosterman, R.E., 2001. Planning Support Systems. ESRI Press, Redlands, CA.

Bueno, J.A., Tsihrintzis,V.A, and Alvarez, L. (1995). South Florida greenways: a conceptual framework for the ecological reconnectivity of the region. Landscape and Urban Planning 33: 247-266.

Burak, S., Ünlü, S. and Gazioğlu, C. (2009). Environmental stress created by chemical pollution in the Marmara Sea (Turkey), Asian Journal of Chemistry, Vol.21(4): 3166-3174.

Carr S., Francis M., Rivlin L.G. and Stone A.M. (1992).Public Space. Environment and Behavior, 415p.

Clerici, N. and Vogt, P. (2013). Ranking European regions as providers of structural riparian corridors for conservation and management purposes. Int. J. Appl. Earth Obs. Geoinform. 21: 477- 483.

Conine, A., Xiang, W.N., Young, J. and Whitley, D. (2004). Planning for multipurpose greenways in Concord, North Carolina. Landscape and Urban Planning 68 (2-3): 271-287.

Cormier L. and Carcaud N. (2009). Les trames vertes : discours et/ou matérialité, Quelles réalités ? Projets de paysage.

Cvejić R., Eler K., Pintar M., Železnikar Š. , Haase D., Kabisch N. and Strohbach M. (2015). A typology of urban green spaces, ecosystem services provisioning services and demands. Green Surge, 68p.

Dridi N. (2012). " Les paradigmes du « développement urbain durable » et de la " qualité de la vie »: du principe à l'action », Les Cahiers d'EMAM 17: 29-42.

Ergen, B. (2013). Euclidean distance mapping and the proposed greenway method in Malta. Journal of Urban Planning and Development 140(1): 04013002.

Erickson, D.L. (2004). Connecting corridors: implementing metropolitan greenway networks in North America. In: Jongman, R.H.G., Pungetti, G. (Eds.), Ecological Networks and Greenways: New Paradigms for Ecological Planning. Cambridge University Press, Cambridge.

Etude de l'Elaboration du Plan Vert du Grand Sousse. (1996). Rapport de la Phase 2, Ministère de l'Environnement et du Développement Durable via Rust VA Project, 111p.

Etude de l'Elaboration du Plan Vert du Grand Sousse. (1997). Rapport Finale, Ministère de l'Environnement et du Développement Durable via Rust VA Project, 120p.

Fábos, J. G. (1995). Introduction and overview: the greenway movement, use and potentials of greenways. Landscape and Urban Planning 33(1): 1-13.

Fábos, J. G., and Ryan, R. L. (2006). An introduction to greenway planning around the world. Landscape and Urban Planning 76(1): 1-6.

Fábos, J.G. (2004). Greenway planning in the United States: its origins and recent case studies. Landscape and Urban Planning 68 (2-3): 321-342.

Fitzsimons, J., Pearson, C.J., Lawson, C. and Hill, M.J. (2012). Evaluation of land-use planning in greenbelts based on intrinsic characteristics and stakeholder values. Landscape and Urban Planning . 106 (1): 23-34.

Flink, C. and Seams, R. (1993). Greenways: a Guide to Planning Design and Development. Washington, DC, 317p.

Forest Research, 2010. Benefits of green infrastructure. Report to Defra and CLG.Forest Research, Farnham.

Forman, R.T., 1983. Corridors in a landscape: Their ecological structure and function. Ekologiya 2, 375-385. 
Forman, R.T. (1995). Land Mosaics. Cambridge University Press, New York.

Forman, R.T. and Godron, M. (1986). Landscape Ecology. Wiley, New York.

Foster, J., Lowe, A. and Winkelman, S. (2011). The value of green infrastructure for urban climate adaptation. Center for Clean Air Policy.

Fremier, A.K., Kiparsky, M., Gmur, S., Aycrigg, J., Kundis Craig, R., Svancara, L.K.,Goble, D.D., Cosens, B., Davis, F.W. and Sott, J.M. (2015). A riparian conservation network for ecological resilience. Biol. Conserv. 191: 29-37.

Gazioğlu, C., Akkaya, M.A., Baltaoğlu, S. and Burrak, S.Z. (2016). ICZM and the Sea of Marmara: The İstanbul Case. The Sea of Marmara: Marine Biodivesity, Fisheries, Conservations and Governanace (Editors: Özsoy, E., Çağatay, M.N., Balkıs, N., Balkıs Çağlar, N., Öztürk, B.): 935-957.

Giordano, L.C. and Riedel ,P.S, (2008). Multicriteria spatial decision analysis for demarcation of greenway: A case study of the city of Rio Claro, $\mathrm{S}^{\sim}$ ao Paulo, Brazil. Landscape and Urban Planning 84: 301311.

Giordano, L.C. (2000). Subs' 1 dios ao Planejamento de um corredor verde na interface-urbano rural do rio Corumbata' 1, no Munic' ipio de Rio Claro-SP. Dissertac , ao (Mestrado emGest ${ }^{\sim}$ ao Integrada deRecursos).Centro de Estudos Ambientais, Universidade Estadual Paulista, Rio Claro, $145 \mathrm{p}$.

Giordano, L.C. (2004). An' alise de umconjunto de procedimentosmetodol' ogicos baseados em SIG, para a delimitac , ao de corredores-verdes (greenways) em cursos fluviais. Doutorado (Doutorado em Geoci^ encias e Meio Ambiente). Instituto de Geoci^ encias e $\mathrm{Ci}^{\wedge}$ encias Exatas, Universidade Estadual Paulista, Rio Claro, $162 \mathrm{p}$.

Gobster, P.H. (1995). Perception of use of a metropolitan greenway system for recreation. Landscape and Urban Planning 33: 401-413.

Haaland, C., Larsson, A., Peterson, A. and Gyllin, M. (2010). Implementing multifunctional greenways in Swedenchallenges and opportunities. In: Proceedings of Fábos Conference on
Landscape and

Planning,Budapest, 8-11 July.

Greenway

Heckscher, A. (1977). Open Spaces: The Life of American Cities. Harper and Row, New York.

Hoşgör, Z. and Yigiter, R. (2011). Greenway planning context in istanbul-halic.: A compulsory intervention into the historical green corridors of golden horn.Landsc. Res. 36 (3): 341-361.

Howard, E. and (1898). Tomorrow: a Peaceful Path to Reform. Swan Sonnenschein, London (2nd edition, 1945, Garden Cities of Tomorrow. Faber and Faber, London.)

IUCN (1980). The World Conservation Strategy. IUCN, UNEP, WWF, Gland.

Jankowski, P. and Nyerges, T. (2001). Geographic Information Systems for Group Decision Making. Towards a Participatory, Geographic Information Science.Taylor and Francis, London and New York.

Jongman, R.H.G., Külvik, M. and Kristiansen, I. (2004). European ecological networks and greenways. Landscape and Urban Planning 68 (2-3): 305-319. Jongman, R.H.G. and Pungetti, G. (Eds.) Cambridge University Press.

Kent, R.L. and Elliot, C.L. (1995). Scenic routes linking and protecting natural and cultural landscape features: a greenway skeleton. Landscape and Urban Planning 33: 341-355.

Kühn, M. (2003). Greenbelt and Green Heart: separating and integrating landscapes in European city regions. Landscape and Urban Planning 64 (1-2): 19-27.

Kullmann, K. (2013). Green-networks: integrating alternative circulation systems into post-industrial cities. Journal of Urban Design, 18(1): 36-58.

Kurdoğlu, O. and Kurdoğlu, B.C. (2010). Determining recreational, scenic, and historical-cultural potentials of landscape features along a segment of the ancient Silk Road using factor analyzing. Environ. Monit. Assess. 170 (1-4): 99-116.

Lindsey, G., Maraj, M. and Kuan, S. (2001). Access, equity, and urban greenways: an exploratory investigation. Prof. Geogr. 53 (3): 332-346.

Lindsey, G., Wilson, J. and Yang, J.A.A.C. (2008). Urban greenways, trail 
characteristics and trail use: implications for design. J. Urban Des. 13 (1): 53-79.

Linehan, J., Gross, M., and Finn, J. (1995). Greenway planning: developing a landscape ecological network approach. Landscape and Urban Planning, 33(1): 179-193.

Little, C. (1990). Greenways for America. Johns Hopkins University Press, Baltimore, MD.

Liu, B. Y. and Yu, C. (2001). Greenway networks planning in USA and its apocalypse to us. Journal of Chinese Landscape Architecture, 6: 77-81.

Liu,K., Siu,K.M., Gong,X.Y, Gao,Y. and Lu,D. (2016). Where do networks really work? The effects of the Shenzhen greenway network on supporting physical activities. Landscape and Urban Planning 152: 49-58.

Loukil B. (2006). Les parcs urbains du grand Tunis, pour qui et pourquoi ?, Mémoire de mastère " Paysage, territoire, patrimoine ", ISA Chott Meriem.

Lyle, J. T. (1994). Regenemtive Design for Sustainable Development. John Wiley, New York

Machado, J.R., Silva, E., Roqutte, R., Rocha, J., Ferreira, JC., Sousa, PM. and Saraiva, MG. 1995). Metropolitan Landscape Planning: a Greenway Vision for the LisbonMetropolitan Area (AML). Special Issue Landscape, 12p.

Mahmoud, A. H. A., and El-Sayed, M. A., (2011). "Development of sustainable urban green areas in Egyptian new cities: The case of El-Sadat city." Landscape and Urban Planning 101: 157-170.

Mason, J., Moorman, C., Hess, G. and Sinclair, K. (2007). Designing suburban greenways to provide habitat for forest-breeding birds. Landscape and Urban Planning 80 (1-2): 153-164.

McMahon, E.T. (1993). Foreward. In: Flink, C.A., Searns, R.M. (Eds.), Greenways: A Guide to Planning Design and Development. Island Press, Washington, DC.

Metropolitan Area (1998). Ph.D. Dissertation in Regional Planning. University of Massachusetts, Amherst,MA, 396p .

Miller, W., Collins, M. G., Steiner, F. R. and Cook, E. (1998). An approach for greenway suitability analysis. Landscape and Urban Planning, 42(2), 91-105.
Mugavin, D. (2004). Adelaide's greenway: River Torrens Linear Park. Landscape and Urban Planning 68 (2-3), 223-240.

Musaoğlu, N., Gürel, M., Uluğtekin, N., Tanık, A. and Şeker, DZ. (2006). Use of remotely sensed data for analysis of land-use change in a highly urbanized district of mega city, Istanbul, Journal of Environmental Science and Health Part A, Vol. 41(9): 2057-2069.

Musaoğlu, N., Şeker, DZ., Kapdaşlı, S., Kaya, Ş. and Duran, Z. (2004). Using remote sensing and GIS for the assessment of visual attributes: a case study of the south coastal zone of Turkey. Fresenius Environmental Bulletin, Vol.13(9): 854-859.

Newton, N.T. (1971). Design on the Land. Harvard University Press, Cambridge, MA.

Orr, S., Paskins, J., Chaytor, S., 2014. Valuing Urban Green Space: Challenges and Opportunities. UCL public policy.

Panduro T.E and Veie K.L. (2013). Classification and valuation of urban green spaces - A hedonic house price valuation. konomiske Råds, 32p.

Pena, S. B., Abreu, M. M., Teles, R., and Espirito-Santo, M. D. (2010). A methodology for creating greenways through multidisciplinary sustainable landscape planning. Journal of Environmental Management 91(4): 970983.

Phua,M. and Minora,M. (2004). A GISbasedmulti-criteria decisionmaking approach to forest conservation planning at a landscape scale: a case study in Kinabalu Area, Sabah, Malaysia. Landscape Urban Plan. 71, 207-222.

Pickett STA, Cadenasso ML. and Grove JM, (2004). Resilient cities: meaning, models, and metaphor for integrating the ecological, socio-economic, and planning realms. Landscape and Urban Planning, 69: 36984.

Pickett STA, Cadenasso ML, Grove JM, Nilon CH, Pouyat RV, Zipperer WC, et al. (2001). Urban ecological systems: linking terrestrial ecological, physical, and socioeconomic components of metropolitan areas. Ann Rev Ecolog Syst 32: 127- 57.

Ribeiro, L. and Barão, T. (2005). Greenways for recreation and maintenance of landscape quality: five case studies in Portugal. 
Landscape and Urban Planning 76 (1-4): 79-97.

Ribeiro, L. and Barão, T. (2006). Greenways for recreation and maintenance of landscape quality: five case studies in Portugal. Landscape and Urban Planning 76, 79-97.

Ribeiro, L.F. (1998). The Cultural Landscape and the Uniqueness of Place: A Greenway Heritage Network for Landscape Conservation of Lisbon.

Salici, A. (2013). Greenways as a Sustainable Urban Planning Strategy. Advances in Landscape Architecture, Dr. Murat Ozyavuz (Ed.), ISBN: 978-953-51-11672.

Shannon, S., Smardon, R. and Knudson, M. (1995). Using visual assessment as a foundation for greenways planning in the St. Lawrence River Valley. Landscape and Urban Planning 33: 357-371.

Smith, D. and Hellmund, P. (1993). Ecology of Greenways. University of Minnesota Press, Minneapolis, MN, 214p .

Store, R. and Kangas, J. (2001). Integrating spatial multi-criteria evaluation and expert knowledge for GIS-based habitat suitability modeling. Landscape Urban Plan. 55: 7993.

Tan, K.W. (2006). A greenway network for Singapore. Landscape and Urban Planning 76 (1-4): 45-66.

Taylor, J., Paine, C. and FitzGibbon, J. (1995). From greenbelt to greenways: four Canadian case studies. Landscape and Urban Planning 33: 47-64.

Toccolini, A., Fumagalli, N. and Senes, G. (2006). "Greenways planning in Italy: The Lambro River Valley Greenways System." Landscape and Urban Planning 76: 98-111.

Turki S.Y and Zaafrane Zhioua I. (2006). Analyse de la répartition spatiale de l'aménagement des espaces verts programmés par les documents d'urbanisme dans le Grand Tunis, Actes du séminaire étape de recherche en paysages, $n^{\circ} 8$, Ecole nationale supérieure du paysage à Versailles, 150p.

Turner, T., (1995). Greenways, blueways, skyways and other ways to a better London. Landscape and Urban Planning 33: 269-282.

Tzolova, G. A. (1995). An experiment in greenway analysis and assessment: the Danube river. Landscape and Urban Planning 33(1): 283-294.
Urbanism Code of Town and Country Planning, Official printing, 1994.

Vasconcelos, P. and Pritchard, M. (2007). A greenway network for a more sustainable Auckland. In Proceedings of the 2nd international conference on sustainability engineering and science.

Viles, R.L. and Rosier,D.J. (2001). How to use roads in the creation of greenways : case studies in three New Zeeland landscapes. Landscape and Urban Planning 55: 15-27.

Walmsley, A. (2006). Greenways: multiplying and diversifying in the 21 st century. Landscape and Urban Planning 76: 252290.

Willemse, L., (MA Thesis) (2010). Community/neighbourhood park use in CapeTown: a class-differentiated analysis. University of Stellenbosch, Stellenbosch, South Africa.

World Commission on Environment and Development, 1987. Our Common Future. Oxford University Press, Oxford.

Wright Wendel, H.E., Zarger, R.K. and Mihelcic, J.R. (2012). Accessibility and usability:green space preferences, perceptions, and barriers in a rapidly urbanizing city in Latin America. Landsc. Urban Plan. 107: 272-282.

Yang, J. and Jinxing, Z. (2007). The failure and success of greenbelt program in Beijing.Urb. For. Urb. Green. 6 (4): 287296.

Zaitzevsky, C. (1982). Frederick Law Olmsted and the Boston Park System. Harvard University Press, Cambridge, MA.

Ziman, Scudo K. (2006). The greenways of Pavia: innovations in Italian landscape planning. Landscape and Urban Planning 76 (1-4): 112-133.

Zube, E.H. (1995). Greenways and the US National Park System. Landscape and Urban Planning 33: 17-25.

Editorial Note: Although some references are not included in the text, they are considered to form the text, so all references submitted by the authors are listed. 